\title{
STRIVING TOWARDS SOCIAL RELEVANCE: NEW CURATORIAL INTERPRETATIONS OF THE SOVIET PERIOD IN ESTONIAN AND LATVIAN MUSEUMS
}

\author{
Anu Kannike \\ (Estonian National Museum, Estonia) \\ Jana Reidla \\ (University of Tartu, Estonia)
}

\begin{abstract}
The main museums in Estonia and Latvia have lately staged new exhibitions that proceed from a contemporary museological approach and reflect the results of historical research. The article compares three cases which present alternative but complementary interpretations of the Soviet period. The authors pay special attention to the application of the biographical method prominent in contemporary cultural research, and the museological method of multivocality. They conclude that in the case of multivocality, effectively addressing different visitor groups is a great challenge to curators. There is a risk that the simplified mediation of contradictory memories and views will leave a gap for visitors with less prior knowledge about the subject of the exhibition. In large exhibition teams, the curator has a crucial role to play in negotiating with team members to prevent the concept from dispersing. In the cases studied, it is possible to observe the curators' views and detect a similar attempt to interpret complex topics through biographies. The analysis concludes that in the context of contemporary museological approaches, the voice of the curator remains essential, especially when mediating exhibits, for they cannot speak for themselves.
\end{abstract}

KEYWORDS: museums, curators, permanent exhibitions, multivocality, Soviet period.

\section{Introduction}

Before the recent centenaries of the independent states, some new large-scale exhibitions opened in Estonia and Latvia in which the treatment of Soviet-period history took a fresh approach, in accordance with some aspects of the modern museology discourse. Over the last few decades, discussions about the meaning of the Soviet heritage have been heated, especially concerning public 
monuments and architecture, ${ }^{1}$ but until recently the presentation of the Soviet period in Estonian and Latvian museums was limited to illustrative rather than analytical overviews. The memorialisation of the Soviet past has also caused tensions in connection with commemorations and the work of expert commissions in finding the historical truth. As Eva Clarita Onken² points out, the mechanisms of inclusion and exclusion do not run exclusively along lines of ethno-cultural belonging, but rather 'many different groups and individuals in society continue to struggle for recognition, representation and participation in the construction of collective memories and political identities in a pluralist democracy.' According to Onken, these struggles can be seen as a healthy by-product of the democratisation process. ${ }^{3}$

But in the 1990s, this era was of little interest in the museum landscape of the Baltic countries, and the few exhibitions that were staged preferred topics from the traumatic past, such as Stalinist repressions. It is characteristic of all the Baltic countries that, despite the condemnation of the crimes of the Soviet regime at state and government levels, extensive state-financed studies ${ }^{4}$ and public commemorative rituals, the communist heritage never became a priority in cultural policy. The first museums dedicated to the Soviet past, mainly the repressions, were often, and some still continue to be, based on private initiatives, voluntary work and donations. ${ }^{5}$ The beginning of the 21st century saw the first

${ }^{1}$ See: K. Brüggemann, A. Kasekamp, "The Politics of History and the "War of Monuments" in Estonia,' in: Nationalities Papers, Vol. 36, No 3 (2008), pp. 425-448; M. Tamm, 'Conflicting Communities of Memory: War Monuments and Monument Wars in Contemporary Estonia,' in: Nation-Building in the Context of Post-Communist Transformation and Globalization: The Case of Estonia, ed. R. Vetik (Frankfurt am Main, 2012), pp. 43-72.

${ }^{2}$ E.-C. Onken, 'Memory and Democratic Pluralism in the Baltic States - Rethinking the Relationship,' in:Journal of Baltic Studies, Vol. 41, No 3 (2010), p. 278.

${ }^{3}$ Onken, 'Memory and Democratic Pluralism in the Baltic States', p. 278.

${ }^{4}$ For example: Estonia 1940-1945: Reports of the Estonian International Commission for the Investigation of Crimes Against Humanity, eds. T. Hiio, M. Maripuu, I. Paavle (Tallinn, 2006); Crimes against Humanity. Latvian Site. http://lpra.vip.lv/ angliski.htm (accessed 202104 19).

${ }^{5}$ Cf. E. Rindzevičiūtè, 'Boundary Objects of Communism. Assembling the Soviet Past in Lithuanian Museums,' in: Ethnologie francaise, Vol. 48, No 2 (2018), pp. 275-286. 
more professional and research-based exhibitions in central state museums, which focused on aspects related to everyday life in the Soviet period: design, food and youth culture. ${ }^{6}$

In studies on the period of socialism, the perspective of the individual and biography have an important position both in history and in the social sciences. These approaches are in line with the principles of multivocality and dialogism emphasised by contemporary museum studies.

Barbara Misztal ${ }^{7}$ stresses the role of memory institutions which provide structures for individual remembering. But in the case of the socialist past, this may result in contradictory meaning-making processes. For example, according to the analysis by the anthropologist and historian Anatoly Khazanov, ${ }^{8}$ Moscow's historical museums, especially the state-owned ones, do not demonstrate a 'fundamental break from the Soviet interpretation of history'. At the same time, there have been alternative attempts to interpret museologically the legacy of Soviet repressions in Russia and other former Soviet repbublics by NGOs and local museums. ${ }^{9}$ The International Society Memorial has tried most systematically, since 1993, to analyse the essence of the Gulag experience and turn it into a tool for democratisation..$^{\circ}$ But these attempts have had a limited effect, and in the 21st century they have been overshadowed by an orthodox interpretation of the memory of repression.

Whereas Russia lacks a public debate on the meaning of the Soviet heritage, in the Baltic States the remembrance and

${ }^{6}$ For more, see: K. Jõesalu, R. Nugin, 'Reproducing Identity Through Remembering: Cultural Texts on the Late Soviet Time,' in: Folklore. Electronic Journal of Folklore, Vol. 51 (2012), pp. 15-48.

${ }^{7}$ Misztal, Theories of Social Remembering, p. 12.

${ }^{8}$ A.M. Khazanov, 'Selecting the Past: The Politics of Memory in Moscow's History Museums,' in: City \& Society, Vol. 12, No 2 (2008), p. 61.

${ }^{9} \mathrm{Z}$. Bogumil, 'Stone, Cross and Mask: Searching for Language of Commemoration of the Gulag in the Russian Federation,' in: Polish Sociological Review, Vol. 177, No 1 (2012), pp. 71-90; E. Anstett, 'Memory of political repression in post-Soviet Russia: the example of the Gulag,' in: Online Encyclopedia of Mass Violence, 2011. https:// www.sciencespo.fr/mass-violence-war-massacre-resistance/en/document/memorypolitical-repression-post-soviet-russia-example-gulag.html (accessed 202104 19).

${ }^{10}$ See a virtual museum of the International Memorial: https://museum.memo.ru/. (accessed 202104 19). 
representation of the topic have generated active public discussions since the beginning of the 1990s." On the other hand, popular culture and the media tend to disseminate a simplified approach to the Soviet period, which mainly brings everyday mythology and symbols to the fore. Therefore, the younger generation especially may lack a deeper understanding of the operating mechanisms of Soviet society and the real challenges that people had to face. Against this background, the new museums have a major role and responsibility in displaying Soviet times. ${ }^{12}$ This article examines recent trends in the Estonian and Latvian museum landscape using three case studies. The cases were selected because the exhibitions were completed close in time and all three address the Soviet period. The first to be completed was the permanent exhibition 'Encounters' at the Estonian National Museum (ENM), which opened in a brand-new museum building in Tartu in October 2016. The National History Museum of Latvia (NHML) opened the exhibition 'Latvia's Century', devoted to the 1ooth anniversary of the Republic of Latvia, in May 2018. In July 2018, the Vabamu Museum of Occupations and Freedom opened a new permanent exhibition 'Freedom without Borders' in Tallinn. Whereas the first two are state-financed institutions, Vabamu was founded in 1998 by the private Kistler-Ritso Foundation, which also built the museum, opened it in 2003, and continues to manage it, although it also receives state support through the Ministry of Culture. The exhibitions focus on (cultural) history and combine chronological-thematic presentations (see Table 1). The temporal framework of the exhibitions is somewhat different, but all of them include the Soviet period. We consider them to be influential exhibitions, as they reflect the current state of both Soviet-period history research

${ }^{11}$ K. Jõesalu, E. Kõresaar, 'Continuity or Discontinuity: On the Dynamics of Remembering 'Mature Socialism' in Estonian Post-Soviet Remembrance Culture,' in: Journal of Baltic Studies, Vol. 44, No 2 (2013), pp. 177-203; E. Kõresaar, 'Life story as cultural memory: Making and mediating Baltic socialism since 1989,' in Journal of Baltic Studies, Vol. 47, No 4 (2016), pp. 1-19; E. Kõresaar, K. Jõesalu, 'Post-Soviet memories and "memory shifts" in Estonia,' in: Oral History, Vol. 47 (2016), p. 47.

${ }^{12} \mathrm{On}$ the responsibility of museums mediating the Soviet period, see: A. Kannike, J. Reidla, 'Vabadusel ei ole piire? Museoloogiline pilk Vabamu uuele püsinäitusele,' in: Tuna. Ajalookultuuri Ajakiri, No 1 (2019), pp. 139-146. 
and museology. Previous exhibitions about the Soviet era have not been as comprehensive in terms of themes and timeframes.

In a contemporary exhibition, the starting point of a project is the team and the concept. The team is led by the chief curator and/or project leader. The concept of the content is formulated by researchers, from both inside and outside the museum, and the architecture, graphics and multimedia are produced by creative agencies. ${ }^{13}$ We analyse the mediation of the Soviet period based on the example of case studies in the context of former representations. The essential concepts from which we proceeded in our research are shared authority, multivocality in exhibitions, and the democratisation of the museums, as they seek to become more relevant to society. This includes the different views resulting from the exhibition team's versatility, and the attempt by the contemporary museum to give a voice to representatives of different groups. The case studies reveal the overall picture that different museums have been able to create by presenting the same period in history.

A discussion about the ideas of a modern, socially relevant museum constitutes the theoretical background of the research. This is followed by an analysis of the exhibition concepts and the final outcomes. The main research issue is the comparison of how the Soviet period as a topical and contested field of research in post-socialist societies is displayed. From this viewpoint, museum exhibitions were studied incomprehensively, and mainly from the point of view of political history and consumption. ${ }^{14}$ Do museums succeed in departing from the simplified approach to the Soviet period that has spread in popular culture and in the media, at the same time as addressing different social groups, and if so how? An academic discussion particularly concerning Baltic museums

\footnotetext{
${ }^{13}$ On recent shifts in exhibition production, see: J. Reidla, 'Who Is Leading the Project? A Comparative Study of Exhibition Production Practices at National Museums in Finland and the Baltic States,' in: Museum and Society, Vol. 18, No 4 (2020), pp. $368-385$.

${ }^{14}$ See, for example: O. Sarkisova, P. Apro, Past for the Eyes. East European Representations of Communism in Cinema and Museums after 1989 (Budapest, 2008); S. Badica, 'The Black Hole Paradigm: Exhibiting Communism in Post-Communist Romania,' in: History of Communism in Europe, No 1 (2010).
} 
has evolved around the issue of whether and to what extent their exhibitions reflect the dominant or hegemonic (nationalist) discourses on the Soviet period..$^{15}$ Although this dispute is based on earlier exhibitions, and not those examined in this article, it provides an interesting background for analysing the new layers in the interpretation of the Soviet heritage.

To collect material for the article, we repeatedly visited the above-mentioned exhibitions from October 2016 to December 2020 and talked and conducted interviews with the curators. ${ }^{16}$ In addition, we used interviews with curators published in the press, scholarly articles published by the curators, and material from the websites of the museums. Being a cross-border study, there are inconsistencies in the sources used, and the language differences impose limits. We were more aware of the reviews and interviews published in the Estonian press, so in the case of Latvia we interviewed the curators ourselves and relied on the extensive catalogue. The exhibition catalogue was also published by the ENM, but not by Vabamu.

\section{A socially relevant museum}

While at the end of the 2oth century the idea of the new museology inspired museums to take greater social responsibility and face the audience, today the changes that have occurred have brought museums considerably closer to their aim to be relevant to society. In order to achieve this aim, museums have devoted

${ }^{15}$ E. Rindzevičiūtè, 'Hegemony or Legitimacy. Assembling Soviet Deportations in Lithuanian Museums,' in: Maps of Memory. Trauma, Identity and Exile in Deportation Memoirs from the Baltic States, eds. V. Davoliūte, T. Balkelis (Vilnius, 2012), pp. 153-177; A.Velmet, 'Occupied Identities: National Narratives in Baltic Museums of Occupations,' in:Journal of Baltic Studies, Vol. 42, No 2 (2011), pp. 189-211; A.Velmet, 'Breaking the Silences: Contradiction and Consistency in Representing Victimhood in Baltic Museums of Occupations,' in: Narratives of Exile and Identity in Soviet Deportation Memoirs from the Baltic States, eds. T. Balkelis, V. Davoliute (Budapest-New York, 2018), pp. 187-211; S. Burch, U. Zander, 'Preoccupied by the Past: The Case of Estonia's Museum of Occupations,' in: Scandia, Vol. 74, No 2 (2010), pp. 53-73.

${ }^{16}$ They all remain anonymous in the article as requested; the notes and recordings of interviews are in the possession of the authors. 
increasingly more attention and resources to communication. In the last decade, the essential components of communication, exhibitions and museum education, have been supplemented by the key word 'mediation', that is, the interpretation of culture. ${ }^{17}$

The new museology has directed museums to proceed from contemporary communication theory and constructivist learning theories, ${ }^{18}$ and the audience is no longer viewed as a 'relatively homogeneous and rather passive mass', but rather as 'diverse, plural, and active. ${ }^{19}$ As a result, more and more communication, design and production professionals have been involved in museum work in recent decades. According to Macdonald: 'Including the material culture of diverse groups and of everyday life is seen as a means of democratizing the museum, of showing its responsiveness to, and inclusion of, various possible constituencies. ${ }^{20}$ The main aim of multivocality is to offer a multiplicity of viewpoints and create bridges between the museum and different social groups, to be socially relevant and responsible. Curators are still learning how to deal with historical contradictions, as the responsibility for finding perspectives is in their hands. Eglè Rindzevičiūtè explains the case of the Museum of Genocide Victims in Vilnius, Lithuania, in an article. ${ }^{21}$ She uses the metaphor of overflow as an analytical tool to understand the role played by the revelation of previously secret experiences in society: the result was an overflow of meanings. According to Rindzevičiūtè, the museum initially failed to manage the overflow of the survivors' own versions of the past into the public presentation of Lithuania's history. So the overflow of meanings contributes to a better understanding of the museum's

${ }^{17}$ A. Desvallées, F. Mairesse, Key Concepts of Museology (Paris, 2010), p. 47.

${ }^{18}$ E.G. Hein, 'Museum Education,' in: A companion to museum studies, ed. S. McDonald (Oxford, 2007); E. Hooper-Greenhill, 'Changing Values in the Art Museum: Rethinking communication and learning,' in: International Journal of Heritage Studies, Vol. 6, No 1 (2000), pp. 9-31.

${ }^{19}$ S. Macdonald, 'Expanding Museum Studies: An Introduction', in: A Companion to Museum Studies, ed. S. Macdonald (Oxford, 2006), p. 8.

${ }^{20}$ S. Macdonald, 'Collecting Practices,' in: A Companion to Museum Studies, ed. S. Macdonald (Oxford, 2006), p. 92.

${ }^{21}$ E. Rindzevičiūte, 'The Overflow of Secrets: The Disclosure of Soviet Repression in Museums as an Excess,' in: Current Anthropology, Vol. 56, No S12 (2006), pp. 276-285. 
desire to exhibit the specific experiences of one community, and to suppress alternative versions of the past. ${ }^{22}$

On one hand, multivocality can be approached as if the curator has no standpoint of his or her own, and only mediates different 'voices': diverse and contradictory viewpoints, from which visitors accept the ones that are suitable to them, ignore the unsuitable ones, or become aware of new ones. According to the constructivist learning theory, they should not be given 'a ready-made product' but be involved in the creation of the experience gained. ${ }^{23}$ Indeed, contemporary museums offer their visitors increasingly more dialogue and freedom of interpretation: each one's personal experience is made to react to stories in the exhibition. In practice, this has added to the workload of museum education, and also brought curating and museum education closer together, so that we can talk about the integrated concept of curating and education. ${ }^{24}$ However, leaving visitors alone in interpreting historical sources may risk applying constructivism in a simplified manner. According to Cheryl Meszaros, ${ }^{25}$ who has criticised this tendency: 'By placing interpretive authority in the hands of the individual', the museum 'not only justifies its failure to communicate, but also it absolves itself of any interpretive responsibility for the meanings it produces and circulates in culture. ${ }^{.6}$ In addition to personal opinions, interpretation should be based on a critical discussion about from where different opinions originate, and the museum should not shirk its responsibility to interpret under the pretext of freedom and democracy. ${ }^{27}$ So proceeding from multivocality does not mean reducing the responsibility of the curator, but rather implies their new competences.

From a methodological point of view, we also have to bear in mind that museums are under continuous construction, where

${ }^{22}$ Rindzevičiūtè, 'The Overflow of Secrets', p. 283.

${ }^{23}$ Hooper-Greenhill, 'Changing Values in the Art Museum', pp. 9-31.

${ }^{24}$ See, for excample: C. Mörsch, A. Sachs, T. Sieber (eds.), Contemporary Curating and Museum Education (Bielefeld, 2017).

${ }^{25} \mathrm{C}$. Meszaros, "Now THAT is evidence. Trackling down the evil "whatever" interpretation', in: Visitor Studies Today, Vol. 9, No 3 (2006), pp. 10-15.

${ }^{26}$ Ibid., p. 13 .

${ }^{27}$ Ibid., p. 15 . 
meaningmaking can be approached as a complex, heterogeneous and collaborative process, which is never settled. ${ }^{28}$ We thus share the understanding that 'to gain a greater insight into the process of exposition formation, critical analysis should attune its method to the specificity of the museum as a particular medium of communication and the cultural sector as a specific institutional and organizational field. ${ }^{29}$ The emerging ideals of culture democratisation also causes intra-organisational strains, if researcher-curators withdraw from staging exhibitions and the leading positions are given to project leaders who lack substantial expert knowledge.$^{30}$ We can say that if a couple of decades ago the situation in which only the 'curator's voice' was heard in exhibitions was criticised, ${ }^{31}$ today practice has also shown that if the curator withdraws, the voice of the designer and project leader can become one-sided. ${ }^{32}$ After decades of discussions about curatorial one-sided authority, according to the anthropologist and museum director Nicholas Thomas, "The new issue is rather that museum restructuring has in too many places downgraded research-based curatorial practice. ${ }^{33}$ Curators have recently again been singled out due to the potential of their substantive knowledge. ${ }^{34}$ Museums need curators, as flexibility, one of the aims of modern museums, insists that 'museum professionals make sense of their collections and stories to varied groups of visitors with different backgrounds and levels of knowledge and experience.'.35

${ }^{28}$ Rindzevičiūtè, 'Boundary Objects of Communism', p. 275.

${ }^{29}$ Ibid., p. 276.

${ }^{30}$ See V. McCall, C. Gray, 'Museums and the "new museology": Theory, practice and organisational change', in: Museum Management and Curatorship, Vol. 29, No 1 (2014), pp.19-35; M. Viau-Courville, 'Museums Without (Scholar-)Curators: Exhibition-Making in Times of Managerial Curatorship,' in: Museum International, Vol. 68 (2017), pp. 11-32.

${ }^{31}$ Hooper-Greenhill, 'Changing Values in the Art Museum', pp. 9-31.

${ }^{32}$ Viau-Courville, 'Museums Without (Scholar-)Curators', pp. 11-32.

${ }^{33} \mathrm{~N}$. Thomas, 'The museum as method (revisited)', in: Curatopia. Museums and the Future of Curatorship, eds. P. Schorch, C. McCarthy (Manchester, 2020), p. 27.

${ }^{34}$ T.A.M. Ewin, J. V. Ewin, 'In defence of the curator: Maximising museum impact,' in: Museum Management and Curatorship, Vol. 31, No 4 (2016), pp. 322-330.

${ }^{35} \mathrm{~J} . \mathrm{K}$. Nielsen, 'The relevant museum: defining relevance in museological practices,' in: Museum Management and Curatorship, Vol. 3o, No 5 (2015), pp. 364-378: 365 . 
While on one hand, to offer better-quality content, museums need curators with research competence, on the other hand, museum exhibitions constitute an important output for researchers to interpret their domain. The exhibited objects need interpretation, which is the curators's job, because objects do not tell stories themselves. ${ }^{36}$ The meanings developed around museum objects are not objective or fixed, but situated and contextual, ${ }^{37}$ that is, we have to consider the multivocal potential of the exhibits. Curators have a great responsibility, as 'on its own, without curatorial, academic, creative and other professional inputs, the visitor experience would risk being empty. ${ }^{\prime 38}$

\section{Different teams and curatorial concepts}

The exhibitions that recently opened in the three Baltic museums represent a new qualitative level in two respects: the implementation of the principles of new museology, and a novel, more comprehensive and balanced interpretation of the Soviet legacy.

Changes in the museum sector in the Baltic States began after 1991, when the independence of the countries was restored. Although the material conditions remained unchanged for years, international communication initiated by the museum staff to educate themselves and communicate with Western colleagues became more active. ${ }^{39}$ Since 2004, the Baltic School of Museology has contributed to the spread of ideas of the new museology, bringing together professionals from different countries and exchanging experiences. ${ }^{40}$ Without a major public debate, a new

${ }^{36}$ S. Lubar, 'Curator as Auteur', in: The Public Historian, Vol. 36, No 1 (2014), p. 73.

${ }^{37}$ Macdonald, 'Expanding Museum Studies'.

${ }^{38} \mathrm{~K}$. Arnold, 'Thinking things through: reviving museum research', in: Science Museum and Research, Spring, (2016). DOI: http://dx.doi.org/10.15180/160505 (accessed 202102 o8).

${ }^{39}$ About regular training in museology, and the professionalisation of museum activities in Baltic states in the 20oos and 2010s, see: J. Reidla 'Curator as an expert and mediator in the paradigm of the new museum: a comparative case study of the Baltic and Finnish national museums' (Dissertationes Ethnologiae Universitatis Tartuensis. Tartu, 2021).

${ }^{40}$ See: A. Jirgensone, 'Baltic Museology School: an example of collaboration in sharing and popularization of International Knowledge,' in: Problems and Develop- 
museum paradigm was adopted in the museum landscape in the 20oos and 2010s, as museum staff took theoretical principles directly from the west, where by that time the idea of the new museology had become established. For more than a decade, Estonian museums have stood out with innovative exhibitions. Current Estonian museum policy focuses on the need to earn revenue and to build a central heritage repository, whereas Latvian museum policy emphasises the need to increase the competitiveness of museums and modernise exhibitions. ${ }^{41}$

In cultural policy, the acknowledgement of the Soviet legacy has been rather slow. For example, in 1992, Latvia's 'Law on the Protection of Cultural Monuments' prohibited the listing of buildings less than $5^{0}$ years old..$^{42}$ In Estonia, the first objects of the material heritage from the period 1940 to 1990 were listed by the Board of Heritage Protection in the late 199os, but the process only speeded up after 2010. The reason for this was mainly ideological, because 'the public preferred to condemn everything from the Soviet time equally.43 There have been no specific guidelines or policy documents issued concerning the Soviet heritage in museums, but, as is mentioned above, the interest of museums in a broader interpretation of the era has remained moderate. In Estonia, in the early 21st century, some aspects of Soviet everyday life were examined by ethnologists and design historians, which resulted in a few exhibitions dealing with food culture and the domestic material culture. ${ }^{44}$ There have also been some smaller exhibitions organised by public and private museums that have

ment Perspectives of Post-Soviet Countries Museums. International Scientific Conference Proceedings, Tbilisi, Georgia, November 7-10, I. Karaia (Tbilisi, 2015), pp. 230-235.

${ }^{41}$ See: Reidla 'Curator as an expert'.

${ }^{42}$ A. Naylor, 'Soviet Modernism's Enduring Baltic Legacy,' in: Jacobin, 9 February 2021 https://jacobinmag.com/2021/o2/soviet-modernism-baltic-architecture (accessed $20210419)$.

${ }^{43}$ R. Alatalu, 'Muinsuskaitse siirdeühiskonnas 1986-2002. Doctoral dissertation (Tallinn, 2012), p. 131.

${ }^{44}$ The exhibitions 'Things in my life' at the Estonian National Museum and the Estonian Applied Art and Design Museum in 2000-2001, 'We eat and drink. Food culture in Soviet Estonia' at the Estonian National Museum and the Estonian Applied Arts and Design Museum in 2006, and 'Youth Summer Days in the Estonian SSR' in 2007 at the Estonian National Museum. 
tried to evoke nostalgia among visitors through everyday Soviet objects or interiors. ${ }^{45}$ The same, rather fragmentary, interpretation of this period is characteristic of Latvian museums.

\section{The National History Museum of Latvia}

Due to a fire in the main building of the National History Museum of Latvia in 2013, exhibitions are housed in a temporary place, and the museum is still waiting for the completion of the renovated Riga Castle, where a completely new permanent exhibition will be built. Therefore, in this analysis, we leave out the permanent exhibition that was made in a hurry, and focus on the special exhibition dedicated to the 1ooth anniversary of the Republic of Latvia in May 2018. Unlike the ENM, which collaborated with individual experts from other memory institutions on the exhibition project, the exhibition 'Latvia's Century' was a joint project with over 60 Latvian museums. As a result, objects from local government and private museums were included in the exhibition, stored in museums in all the regions of Latvia: Kurzeme, Sēlija, Vidzeme, Zemgale and Riga. ${ }^{46}$

The project was coordinated by the National History Museum of Latvia, whose research director also became the general leader of the project. The ten-member management group involved experts responsible for different topic areas from the seven Latvian museums $^{47}$ (the National Museum of Art, the Museum of the Occupation, the Literature and Music Museum, the Museum of the History of Riga and Navigation, the War Museum, the Museum and Research Centre 'Latvians Abroad', and the Cēsis History and Art Museum). In addition to the general manager of the project, there was a leading curator from the NHML, who curated five out of ten topics and compiled the general concept of the exhibition

${ }^{45}$ For example, the exhibition 'The Golden Sixties' at the Tallinn City Museum or 'No bananas. A time travel into the Soviet Time' in 2017 at the Tallinn TV-tower.

${ }^{46}$ The map shows museums which participate in the exhibition 'Latvia's Century': https://latvijasgadsimts.lv/museums?lng=en (accessed 202104 19).

${ }^{47}$ The 'Latvia's Century' exhibition website. http://latvijasgadsimts.lv/?lng=en (accessed 20210207 ). 
on the basis of joint discussions. ${ }^{48}$ The initial concept was presented to a wider audience (all Latvian museums and certain people outside the museums) for an opinion. Afterwards, some changes were made to the concept, the most important of which was the addition of the topic of collective farms.

In formulating the concept, existing exhibits were not taken into consideration, but rather what aspects to emphasise and what to bring to the fore. Thus, it was not based on the material available in the museum's collections. Instead, the importance of the exhibition in presenting the results of historical research was acknowledged. Thus, responsibility was taken for the impact of the curators' decision in choosing which topics to emphasise. ${ }^{49}$ It was only after the concept was approved that additional artefacts were collected,,$^{\circ}$ and more interviews were conducted for biographies. Thanks to the joint work of museums, there was no danger of a shortage of exhibits for a topic; however, these choices had to be more thoroughly substantiated. The biographies exhibited were chosen from the different regions of Latvia, and various nationalities are represented. Collaboration between museums in offering exhibits and sharing the concept to get opinions thus followed the principles of an inclusive museum on the organisational level.

The 'Latvia's Century' exhibition concentrates on the identity-based history concept. The museum presents alternative visions of the Latvian identity and future from the 19th century up to today. Conceptually, the diversity of individual experience demonstrates the complexity and difference of historical periods, as well as the continuity of experience of Latvianness, certain values, and ideas. ${ }^{5^{1}}$ The research director emphasiszed that the national museum cannot follow trends too much, but has to proceed from scientific research when exhibiting. The mission of the

${ }^{48}$ Curators interviewed by the authors, digital recording, 5 December 2018, Riga.

${ }^{49}$ Curators interviewed by the authors, 5 December 2018.

${ }^{50}$ According to the leading curator, out of the 6,ooo objects offered, about 1,000 were finally displayed.

${ }^{51}$ Latvia's Century: Museums for Latvia's 1ooth anniversary. Exhibition catalogue (Riga, 2018), p. 20. 
NHML is, by speaking about history, to help citizens understand their country and their state..$^{2}$

As we compare the teams and curatorial concepts, in the case of the Vabamu team, the experimental approach can be highlighted. It was obviously affected by the team's conscious opposition to the previous permanent exhibition. The Vabamu team was quite small, and for most of the curators and administrators of the younger generation, the exhibition served as their first experience. In contrast, the ENM team was large. This was a challenge for the general curator, who also curated some topics, as she had a great organisational and administrative load. The most problematic issues arose from attempts to preserve the integrity of the concept, while orchestrating and adapting the strong visions of the design team. When we compare how the working groups operated, in the relatively small one at the NHML the main right to decide was conferred on museum professionals. Ten experienced museum researchers discussed all the essential issues jointly, but one of them participated in all the meetings devoted to sub-topics (for example, with designers), in order to keep the focus on the initial concept, and also edited texts for the exhibition.

\section{The Estonian National Museum}

Similarly, 'Encounters' at the ENM was the result of a reinterpretation of the entire museum. In comparison with the time when the previous permanent exhibition was staged (1994), the museological way of thinking and research areas of ethnology had changed, and there was a new generation of researchers working at the museum. The museum, which until then had been known as mainly representing 19th-century Estonian peasant culture, was inclined to create a more powerful image of a national museum in the new building, which today means an approach focusing on the diversity of the population rather than one ethnos. ${ }^{53}$ The

\footnotetext{
${ }^{52}$ Research director interviewed by the authors, digital recording, 7 November 2017, Riga.

${ }^{53}$ K. Rattus, 'Paljuhäälne Eesti: Kultuuriloo püsinäituse 'Eestimaa kahekõned' koostamisest Eesti Rahva Muuseumis,' in: Õpetatud Eesti Seltsi aastaraamat (Tartu, 2014), pp. 108-109.
} 
professionals involved in shaping the new museum identified with 'a discourse which is intellectual, academic and postmodern', arguing that the key issue in the transformation process of the Estonian National Museum was 'whether the museum will be able to substitute or enrich ethnic nationalism with civic nationalism. ${ }^{54}$

The concept of the new exhibition was elaborated by the research department of the ENM. In the initial phase, opinion formers from different spheres of life were involved, in order to reflect the social expectations of the ENM. When topic areas had been defined, an interdisciplinary team was formed: more than 40 people altogether. The chief curator who led the project was a researcher from the ENM with more than 20 years of exhibition experience. Universities, museums and research institutes were involved. Artefacts were also received from archives and libraries, as well as private collections. The film and design team were involved in the initial phase of the concept creation, and therefore also played an essential role in the decisions about substantive issues. Based on the interviews, ${ }^{55}$ we argue that in the ENM's case, the influence of designers and creative agencies in decision making was significantly greater than in the Latvian case. In the case of Vabamu, the importance of design is visually noticeable: a large space is given to the art installation.

One of the objectives was to present the most recent research results. Inspired by the new museology, the aim was to apply two-way communication, multivocality, and the empowerment of audiences. ${ }^{5}$ The team wanted to present on one hand a common historical experience, and on the other hand the national and social diversity of this experience and its dynamics in time. The selection of topics focused on 'cultural changes and phenomena

\footnotetext{
${ }^{54}$ P. Runnel, T. Tatsi, P. Pruulmann-Vengerfeldt, 'Who Authors the Nation? The Debate Surrounding the Building of the New Estonian National Museum,' in: Democratising the Museum: Reflections on Participatory Technologies, eds. P. Runnel, P. Pruulmann-Vengerfeldt (Frankfurt-am-Main, 2014), pp. 30-32.

${ }^{55}$ Curators interviewed by the authors in Tartu (ENM) 28 September 2018 and 22 March 2019, and Riga (NHML), 5 December 2018.

${ }^{56}$ K. Rattus, 'Paljuhäälne Eesti', p. 105.
} 
that probably most of the Estonian population experienced personally at the time. ${ }^{57}$

The exhibition proceeds from the notion of everyday culture: to illustrate the concept, fieldwork was undertaken in order to collect more material (artefacts and photographs, interviews ${ }^{58}$ ). At the request of the curators, the designers' initial plan to display artefacts minimally was given up, although in interviews and conversations the curators admitted that seeking compromises over the display of artefacts lasted until the end of the working process.

\section{Vabamu Museum of Occupations and Freedom}

Changes in the Estonian Museum of Occupations began in 2015, when the museum acquired a new director. She initiated the campaign for the name change of the museum, which caused a heated argument in Estonia. ${ }^{59}$ Vabamu $^{60}$ staged the new permanent exhibition with a completely new and rather small team. The chief curator was the exhibitions manager of the museum, and, in addition, the team involved three younger-generation historians with doctoral degrees, a dramaturgist, and a communications expert. ${ }^{61}$ The new permanent exhibition was meant to express the reinterpretation of the museum, with the aim of attracting younger audiences and highlighting contemporary socially relevant topics, instead of looking back to the past. ${ }^{62}$ The building of the museum was still new and modern, but the exhibition was redesigned, and with the extension of the displays to the basement floor, the exhibition space doubled.

${ }^{57}$ Kohtumised: Eesti kultuuriloo püsinäitus Eesti Rahva Muuseumis (Exhibition Encounters catalogue) (Tartu, 2018), p. 9.

${ }^{5}$ For example, interviews with Russians who had moved to Estonia after the Second World War, emigré Estonians who had fled to the West, etc.

${ }^{59}$ E. Kõresaar, K. Jõesalu, 'Okupatsioonide muuseumist Vabamuks: Nimetamispoliitika analüüs,' in: Eesti Rahva Muuseumi aastaraamat, 6o (Tartu, 2017), p. 142.

${ }^{60}$ The previous name of the museum was the Museum of Occupations, the name Vabamu is derived from the Estonian word vaba [free].

${ }^{61}$ Freedom without Borders, Vabamu's permanent exhibition website: https:// www.vabamu.ee/plan-your-visit/permanent-exhibitions/freedom-without-borders (accessed 20210207 ).

${ }^{62}$ E. Kõresaar, K. Jõesalu, 'Okupatsioonide muuseumist Vabamuks', p. 142. 
The curators at Vabamu opposed its former image by not wanting to see the museum as a 'privileged' mouthpiece for the victims of occupation, that is, the repressed or dissidents, but also to offer space to others, especially the younger generation, who did not identify with the 'suffering narrative', but might be involved in discussions about the meaning of freedom in the contemporary world. In his critique of the previous exhibition, Velmet claimed that by presenting the Estonian people as victims of the Second World War, the Estonian people were given the myth of justice and a special uniqueness. He also pointed out that 'victim status' excludes the possible existence of other victims, 'or worse yet, the possibility of seeing Estonians as perpetrators of oppression, ${ }^{6}{ }^{63}$ So he considered it necessary to recognise the consequences of the Holocaust in Estonia, and to abolish the requirement of the 'special dignity' of Estonians. Changing this approach was the goal of the new permanent exhibition, of which one of the curators was Velmet.

The starting point for the Vabamu curators, stating that 'the museum does not tell one specific story but has to address many people from different socio-economic strata, with different ethnic backgrounds or just different worldviews, ${ }^{64}$ clearly proceeds from the principle of multivocality. In addition to this, the curators expressed the wish to generate discussion, and, instead of bespoke estimations, to make the younger generation think about how they would behave in similar situations, and what they would do in a different way. While the new museology has criticised 'social exclusion' and the presentation of the historical narrative from the position of privileged classes and ethnic groups, ${ }^{65}$ here the preference for the viewpoint of the victims of occupations and Soviet colonisation (on which the former exhibition was based) was criticised and recommended to be left out. ${ }^{66}$ It should be

${ }^{63}$ A. Velmet, 'Occupied Identities', p. 197.

${ }^{64}$ H. Kõiv, 'Privilegeeritud ajaloo lõpp: muuseum depolitiseerimas okupatsiooni,' in: Müürileht, 21 February 2017. https://www.muurileht.ee/privilegeeritud-ajaloo-loppmuuseum-depolitiseerimas-okupatsiooni/ (accessed 20210208 ).

${ }^{65}$ R. Sandell, 'Museums as Agents of Social Inclusion,' in: Museum Management and Curatorship, Vol. 17, No 4 (1998), pp. 401-418.

${ }^{66}$ For more, see: A. Velmet, 'Occupied Identities', pp. 189-211. 
mentioned that in Estonia the role of the interpreter of occupations is largely performed by this museum, as there are no other museums in Estonia that specifically treat the occupation experience; ${ }^{67}$ also, until today, there was no display devoted to the extensive Estonian refugee diaspora ${ }^{68}$ in the West.

Compared to the previous exhibition, the new one at Vabamu expanded the range of topics: new material was collected, in the form of interviews and artefacts, photographs and documents. Although the way repressions were represented was changed, the formerly displayed artefacts, some of them donations, were also used to open up this topic. But the concept proceeded largely from the idea, not the artefacts, and the leading Estonian experts on repressions and the Soviet period were not involved.

\section{Curatorial choices: representing the Soviet period}

Following the position formulated by the curators of the NHML that the curator's choices influence the presentation of the results of historical science to the public, we identify the most important 'choices' in these cases.

\section{The National History Museum of Latvia}

At the 'Latvia's Century' exhibition, the Soviet period is chronologically divided into four parts (see Table 1), where each period in turn has a thematic focus: I resistance and migration; II ideological pressure and kolkhozes; III home and nature; IV memory recovery and national symbols. Each part highlights a certain aspect of the collective experience: managing poverty and political pressure, life in the countryside, the expression of the feeling for the homeland (Latvia), and the awakening of civil society. This choice enabled the curators to represent the dynamics and diversity of the Soviet period, as well as people's constant need to adapt to the circumstances.

${ }^{67}$ To a certain extent, the KGB Cells Museum, a branch of the Tartu City Museum, has filled the gap.

${ }^{68}$ The Estonian diaspora was formed mainly from people who fled to the West from the Soviet occupation in 1944. 
Alongside interest in the material culture in anthropology, ${ }^{69}$ artefacts once again occupy the place of honour in museum exhibitions. Mario Schulze has shown, ${ }^{70}$ based on the example of German museums, how during the past 50 years the role of artefacts has changed from 'authentic portrayals of yesterdays' to 'mediators and agents of the topic displayed'. The social life of the artefacts displayed in the Latvian exhibition has been as dramatic as people's lives were during that period. Artefacts operate as bridges connecting periods of time, by means of which the curator directs the visitor to think back and forth in time. The curator's text builds bridges to the exhibits; for example, an elegant chest of drawers from the 1920s or 1930s, holding tableware and trinkets is not just a stylish embellishment, as the curator's text tells us how after the Second World War, 'going through old keepsakes from peacetime, one could sense the living standards of the past'. By means of recycled items, the curator shows people fighting hardship as active agents, not as victims of the system. In addition to objects as bearers of memory, the exhibition also highlights landscapes, physical (home) and spiritual spaces (literature, music), as anchors of the continuity of the Latvian identity. In comparison with Estonian museums, the Latvian exhibition uses more creative arts, literature, paintings and music, to illustrate emotions and the spirit of the era. This successful synthesis is probably a bonus resulting from the collaboration between museums.

Biographies play a crucial role in the 'Latvia's Century' exhibition, both in terms of volume and impact. They open up the subjective and emotional side of history. The curators' choices are intertwined with the subject's own voice: letters, diaries, and reminiscences of family and friends are displayed, and also, if possible, flashbacks in the form of text or film clips. Biographies mediate the intertwinement of eras, parallel and similar developments. The

${ }^{69}$ C.S. Greene, 'Museum Anthropology,' in: Emerging Trends in the Social and Behavioral Sciences: An Interdisciplinary, Searchable, and Linkable Resource, eds. R. Scott, S. Kosslyn (New York, 2015), pp. 1-15.

${ }^{70} \mathrm{M}$. Schulze, 'Things are Changing: Museums and the Material Turn,' in: Museological Review, No 18 (2014), p. 51 . 
clear structure of presenting biographies throughout the exhibition makes it easier to embrace multivocal information.

The approach to the totalitarian ideologies of the years 1940 to 1945 proceeds from the viewpoint of Latvia and the Latvians; therefore, Soviet and Nazi propaganda is displayed side by side, as well as material from prisons and concentration camps. In the display of the Stalinist period, the topic of kolkhozes is presented reasonably in detail, as it was in the countryside that the upheaval in everyday life and changes in the landscape were the most radical and the consequences are most palpable today. The voice of the curator speaks about country people's obligations and the pressure, and the essence of the era is expressed well in selected symbols: the writing desk of the head of a collective farm, and behind his back a window with bars in the shape of rays of sun.

The dilemmas of the era are also opened up from the point of view of the average person in the treatment of the periods of the thaw, and 'mature' socialism in the years 1953 to 1985 . The curators focus on the relationship between public and private, which also occupies an important position in academic approaches to the socialist era. ${ }^{71}$ From the point of view of private life, the concept of the 'normalisation' of Soviet power is disputed. Although in private life people did not suffer from such severe repression and hardships any more, 'personal Latvia included independence lost after occupation, families on the other side of the Iron Curtain, concealed cultural heritage, memories of repressions, and fears of Russification. ${ }^{72}$ Along with this, groups supporting public rituals and social control are introduced, such as pioneers, veterans and work heroes.

The deeper meaning of everyday life and the domestic world of things are illustrated by an expressive sub-heading 'Latvia as a Personal Space. The privacy of family life and participation in cultural life helped to preserve Latvianness, and distinguish it from the Soviet reality. An alternative experience of history and

${ }^{71}$ Borders of Socialism. Private Spheres in Soviet Russia, ed. L. Siegelbaum (New York, 2006); P. Bren, M. Neuburger, Communism Unwrapped: Consumption in Cold War Eastern Europe (Oxford, 2012).

${ }^{72}$ Latvia's Century, p. 170. 
culture existed in the private sphere. The contents of the storage cupboards in the living room is fascinating to the visitor, but it is not a mere curiosity. The curator's text reveals the essence of the system: shortages made people stockpile fabrics, cleansers and alcohol. Cupboards also held goods brought from abroad or sent by relatives, as well as those obtained on the black market. This way, the cupboard symbolises well the half-closed world, which was still permeated by an alternative materiality and spirituality. Displaying the domestic interior, literature and art distinguishes the Latvian exhibition from the one in Estonia, where interiors are not so impressively represented. In the Latvian exhibition, everyday life is more thoroughly contextualised, especially compared to Vabamu, which does not open up the background and context of a kitchen interior of the 1970s and 1980s. The ENM presents the domestic interior with bedrooms from the 196os to the 1980s, where the bed is the dominant element, and other pieces of furniture are represented minimally; and the background audio texts are about people's reminiscences of their homes, not about the displayed interiors.

Both in Estonia and in Latvia, emotional contact with nature and folk traditions were important sources of the national identity during the Soviet occupation. The Latvian curators have also extended the metaphor of home to the environment: Latvia was perceived as the homeland, not as a Soviet republic. Despite the binary structure of the exhibition, the design solutions, exhibits and the relationships between them talk about the intertwining of the public and private spheres in Soviet everyday life, as has also been highlighted in cultural-theoretical research. ${ }^{73}$ In the mediation of this period, the topic of cultural continuity is also considered as essential, by showing how poetic language could express more than other writings. Freedom could be retained by the creation of culture: this is an important idea that is also pointed out by the ENM, but the Vabamu exhibition ignores this line of thought.

${ }^{73}$ Socialist Spaces: Sites of Everyday Life in the Eastern Bloc (Oxford, 2002); A. Yurchak, Everything Was Forever Until It Was No More: The Last Soviet Generation, eds. D. Crowley, S.E. Reid (Princeton, 2005); A. Kurg, 'Boundary Disruptions: Late-Soviet Transformations in Art, Space and Subjectivity in Tallinn 1968-1979' (PhD dissertation, 2014). 
The Latvian exhibition has brought the last years of the Soviet period (1986-1991) into focus as a social movement towards independence. The curators have taken the position that political freedom was not luck, but the result of the nation's mission-oriented fight and the continuity of memory, which involved opposition and dramatic choices.

The 'Latvia's Century' curatorial text provides comprehensive information, but it is analytical rather than being neutrally charged, asking questions and making us think. On the other hand, the articles are visitor-friendly, and short, informative and in one style throughout the exhibition. The curatorial text describes collective experience as a chronological line underlying the exhibition. The foreground is occupied by people, as active shapers of history, interpreters of processes, who deal with problems and choices in different ways. In general, the Latvian exhibition focuses on the evolution of the national idea through multinational actors, and social, ethnic and geographic diversities are expressed in biographies.

\section{The Estonian National Museum}

The Soviet period is depicted in different parts of the exhibition at the ENM, mainly in the thematic display under the heading 'Parallel Worlds. Parallel Lives', and in the part called 'Life behind the Iron Curtain', divided into the sub-topics 'Journeys in Time', 'Changing Country', 'The Iron Curtain', 'Culture into Masses' and 'Coping in the Shortage Economy', in the chronological display of Estonian cultural history 'Path of Time'.

The display 'Parallel Worlds. Parallel Lives' focuses on everyday life during the Cold War, juxtaposing different viewpoints and giving a voice to 15 people. Life in Soviet Estonia is represented through the narrators' personal items and life stories. In selecting topics uniting the groups, the curators proceeded not from political categories but from emotional terms used in biographies, such as 'happiness', 'chance', and 'success'. Separate 'islands' depict insights into different decades via vivid memories or the experiences of the same people (for instance, staying in Czechoslovakia in 1968 during the Soviet invasion). 
The curators have not avoided complicated or delicate topics, which is a frequent problem in Baltic historical interpretations, ${ }^{74}$ and as a result, the picture is balanced. For example, in the case of the postwar immigration following the Soviet occupation, its problematic consequences, such as national tensions, are discussed. On the other hand, the hardships experienced by the newcomers are depicted, as well as the fact that the immigrants were not only Russians: Belarussians' and Ingrians' stories and artefacts are also represented. Although the exhibition also presents comprehensive overviews of biographies, the curators have deliberately brought to the fore single colourful stories, in order to mediate history, as it is talked about in everyday life. The exhibition in 'Parallel Worlds' can boast a good balance between factual information and highlighting the peculiarities of different eras, by means of dramatic and emotional stories and items with symbolic meaning. The curators have convincingly solved the idea of multivocality: the structure helps to systematise different 'voices', and several ethnic groups and communities so far marginal (such as miners) were included in staging the exhibition. ${ }^{75}$ But the design does not support the concept; rather it interferes with and muffles the curators' voices. Despite the curators' request, ${ }^{76}$ neither the general topic of 'Parallel Worlds' nor the headings of thematic islands are marked in the exhibition hall. The beginning, end and structure of the Soviet-period display can be confusing to a visitor attending the exhibition without a guide, and the poor quality of the text in the earphones is disturbing.

In the part 'Journeys in Time', one display contains thematically coherent sets of objects from the same period of time. By juxtaposing the personal items of people who were deported by the Soviet authorities to Siberian prison camps, fled from the war to the

${ }^{74}$ For more, see: A. Rahi-Tamm, 'Our Untold Stories: remembering the Soviet time from a historian's viewpoint,' in: Cultural Patterns and Life Stories, eds. K. Jõesalu, A. Kannike (Tallinn, 2016), pp. 77-103.

${ }^{75}$ For more, see: K. Rattus, T. Anepaio, 'Managing the Other: Stories of the Estonian Russian-speakers in the Estonian National Museum's core exhibition,' in: Diffcult Issues. ICOM International Conference 21-23 September 2017 Helsingborg. Proceedings, ed. A. Ziemer (Heidelberg, 2019), pp. 93-104.

${ }^{76}$ A curator's personal communication with the authors, 22 March 2019. 
free West, or immigrated to Estonia from the more remote regions of the Soviet Union in search of work, the curators have tried to create dialogues between the items. This expresses the ethnic and social mosaic of Estonia, as well as different life choices made at the same time. In its idea, it is close to the biographical insights into different eras that are used at the NHML. The curator's text supplements the items with background information, pointing out the reasons for the comings and goings, and the consequences of the migration processes.

The approach to Soviet-period country life focuses on the Sovieticisation of the landscape and typical blocks of flats, a witty expression of which in the exhibition is an installation called Water from the tap, a sink with cleansers and a hand-pump, referring to plumbing problems. While the Latvian exhibition focuses on collective farmers' obligations, environmental pollution, poverty and negligence, the curators at the ENM have also brought to the fore some positive aspects of life on a collective farm: the rise in living standards from the 1970s, and the unique architecture at the centres of prosperous collective farms. In comparison to the integrated approach of the Latvian museum, the insight into the topic offered by the ENM remains fragmentary, patrtly caused by the vagueness of the routes in the exhibition, so that the visitor may lose track of the topic.

The modernisation and relative Westernisation (compared to the rest of the USSR) of Soviet-period life in Estonia are illustrated by the displays of hard-to-get items. The display of the production of local Estonian footwear factory demonstrates, at first sight, attractive shoes from that era. But the curator's text shows another side of the reality: most of the best production was exported to the RSFR, whereas the most unimpressive and rather uncomfortable shoes remained in Estonia. In order to open up the multi-layeredness of Soviet everyday life, the pairs of shoes are accompanied by stories about how complicated it was to obtain them, which also makes the context understandable to foreigners and schoolchildren. Jeans are also a rewarding exhibit, showing the ambivalent attitude of the Soviet authorities to Western mass culture, and how desirable this cult item was to youth. 
Both the NHML and the ENM emphasise the role of culture in the preservation of the national identity and memory during the Soviet period. The ENM's permanent exhibition includes the family library of a researcher on original shelves, specially collected for the exhibition. This exhibit also indicates the crucial role of other art forms in expressing free thought, and the role of creative people as opinion formers. We can give an example of the importance of the curator as the decision maker: whereas in the case of cinema, its role as a mediator of the Western way of life is mentioned, the text about television fails to mention the weighty influence of Finnish TV, which was Estonia's great peculiarity in the Soviet Union.

The curatorial text at the ENM is multi-voiced, which is expressed in the way information is mediated, and in how the Soviet-period topics are positioned in different parts of the display. The multiplicity of curators intensifies the impression of a kaleidoscope: the texts are written in different styles, and manifest a different level of generalisation. 'Encounters' is definitely not an easily comprehensible exhibition: since it is largely based on intuitively interpretable visual language, the exhibition is far from unambiguous. So it favours the intellectual visitor who will spend at least a couple of hours at the exhibition, reading and delving into the captions, who is patient enough to watch the films and study the touchscreens, and through all this make their own interpretations. Unfortunately, there are places where the curator's concept is not adequately supported by the design.

\section{Vabamu Museum of Occupations and Freedom}

The Soviet period is approached here from two points of view: 1) the nature of power and people's choices; and, 2) everyday life in the Soviet period. The curators have greatly contributed to novel technical solutions: the wall texts are short and comprehensive, but as the exhibits are not labelled, the rest of the information is available only on the screen of the e-guide and from earphones. The Soviet-period topic opens up most informatively and interestingly through programs presented on touchscreens. The information on 
screens explains things that are self-evident to people who lived in Soviet Estonia, but not to the younger generation or to foreigners. For example, the symbolism in Soviet-period posters is explained well: by clicking on the pioneer's neckerchief, you can read what a pioneer was. The screen 'Anatomy of Totalitarianism' presents a comparison of totalitarianism in Stalinist Russia and Nazi Germany: ideologies, elements of propaganda, etc. Vabamu suggests that visitors compare their personal options with those available to people in the past, and the touchscreens provide a good solution for it, enabling the perception of serious dilemmas with no good solutions (for example, a young man's choice between his bride ['public enemy'] and studies at university).

In the approach to the Soviet period, the curator's focus is on authority as an anonymous force, and no examples are presented of the nomenclature or authority. Also, no voice is given to dissidents or the organisers of protest actions by schoolchildren and youth. So although the concept foresaw manifestations of citizens' courage, many aspects of the struggle for freedom have been left out. Contrary to the clearly structured and informative touchscreens, the audio text on the earphones ${ }^{77}$ is simplistic, and asks rhetorical questions, presenting little information to answer the questions posed. It is not enough to understand the background, and specific Soviet-period expressions (Little Octobrists, alternative kitchen communities) are used without explanation. It can be argued that while the information presented on the digital screens refers to material academically elaborated by the curators, the topics raised in the audio text about the nature of the Soviet regime, the occupation and collaboration remain sketchy. Vabamu has entirely avoided the topic of rural life in the Soviet period, although the ruining of the agrarian lifestyle was of crucial importance in the perpetuation of the occupation.

The curators' intention was not only to give a voice to the victims of the occupation, but also to approach the topic from

${ }^{77}$ The audioguide is a practical tool for the individual visitor, but for older visitors with less digital experience, and perhaps also with reduced mobility, combining information from the audioguide and physical displays is too complicated (see: Kannike and Reidla, 2019). 
different angles. Pääbo and Pettai ${ }^{7}$ referred to this approach as 'de-nationalizing and individualizing the occupation narrative'. It is probably for this reason that visitors are offered contradictory memory fragments (for example, the narrator who admits that he honestly believed that the kulaks who were to be deported were dangerous). The audio guide speaks about Estonians' own responsibility for the occupation and colonisation, gullible recipients of the new propaganda, and cynical collaborators with the new authorities. Unlike the ENM and the NHML, Vabamu does not approach the topics of colonisation and immigration, the predominantly Russian-speaking people who settled in Estonia, or the policy of Russification.

Only a few artefacts are used to open up the topic of the Soviet period. The most conspicuous exhibits here are a soda vending machine and a kitchen interior. When displaying everyday life, there is a risk of sticking to a level of restaging details that seem odd to today's visitor. Even the inclusive museum has to take responsibility for contextualising, in order not to be just an entertainer. Thematic reconstructions of everyday socialist life can be seen in several East European and Estonian museums, so Vabamu's solution is somewhat unoriginal, and, as such, offers no especially novel interpretational quality.

There is some interactive inclusion in the exhibition, but the virtual furnishings of the Soviet-period living-room lack an educational point. When picking out pieces of furniture, visitors may get the answer 'Out of stock', but they learn nothing about the chronic shortage of furniture, or that 'free living quarters' was a bargaining chip for the Soviet authorities and the local nomenklatura to manipulate and control people. A good means of mediating the Soviet period is the anecdotes covering the walls, although visitors who did not live in that period (foreigners and the younger generation) need additional explanations to understand the real background to the absurdities.

${ }^{78}$ H. Pääbo, E-C. Pettai, 'A Museum of Memories: The New “Vabamu” in Tallinn,' in: Cultures of History Forum, 27 March 2019, 4. DOI: https://doi.org/10.25626/oog6 (accessed $202102 \circ 8$ ). 
At Vabamu, the curatorial text is strongly problem-centred and unconventional. The curators' aim is not to present historical facts, but rather to offer a consistent 'performance', with the alternating selection of music, the voices of different actors, narrators' remarks and questions creating a dramatic tension. As a rule, the curators overestimate their audience's general knowledge. ${ }^{79}$ It is presumed that the visitors construct their own knowledge on the basis of the information offered by the museum, and gain valuable experience. But what could the experience be like, constructed by today's youth, of historical events that happened several decades before their birth, since nearly 30 years have passed since the Soviet period? In this case, in order to understand the meaning of the display, history teachers have to explain things before and after the visit, or grandchildren should visit museums with their grandparents. However, we can conclude from the design, the technical solutions and the performative approach that Vabamu's exhibition is oriented towards youth. At the same time, the exclusion of an important target group, the repressed and the freedom-fighters of the older and middle generations, as well as not involving more outstanding academic experts, is strongly felt.

In the concept of the Soviet period, the museum highlights the individual's freedom of choice, and in the case of repressions, also resilience as important values. In terms of the name of the museum, we would expect a more detailed representation of the experience of occupation and the meaning of the struggle for freedom in different periods in Estonian history. The question of where freedom came from remains unanswered, and the agency of the nation as a whole in occupied Estonia and in exile remains unexplored. In this regard, the curator's voice remains dumb.

\section{Conclusion}

New curatorial interpretations of the Soviet period in three Baltic museums are based on extensive collection work and research, and contemporary academic discourses. The museums take into

${ }^{79}$ P. Vergo, 'The Reticent Object,' in The New Museology, ed. P. Vergo (London, 1989), p. $5^{2}$. 
account, to a greater or lesser extent, the latest approaches in historical research and contemporary exhibition trends. From the museological discourse, the socially relevant and democratic approach is emphasised. The curators faced a great challenge to address different social groups, which is well suited to the multi-vocality tool. Multi-vocality is represented through diaspora communities in all three exhibitions. The Latvian exhibition highlights multi-nationality, whereas the ENM involved the Russian-speaking population of Estonia. The exhibition at the ENM also brings to the fore the topic of parallel communities that emerged as the result of immigration and forced exile.

All three exhibitions make use of the biographical method, the NHML and the ENM more extensively than Vabamu. Showing individual historical experience demonstrates the democratisation of museums: they have brought to the fore not the lives of historical figures, but, above all, the changes that occurred in ordinary people's everyday life. The museums discuss Soviet repressions and ideological pressure from different points of view. The home and the private sphere are also represented in all of them: most completely at the NHML, and the least contextualised at Vabamu. Culture as the maintainer of the identity and a means of silent resistance is approached most completely at the NHML, and to a certain extent also at the ENM.

The harmonisation of voices in the extended exhibition teams was carried out at different levels. In order to harmonise the curators' voices, efficient teamwork, clear points of view of the leading curators, and inter-museum collaboration are needed. In the Latvian exhibition, the choice of topics is the most transparent and based on the catalogue text, and the concept is the clearest. At 'Latvia's Century', the principle of democracy and involvement was pursued by forming an extensive network of local museums, thanks to which the cultural and memory heritage of all Latvian regions was represented. In recent years, the importance of design and the influence of designers on the exhibition team has increased. At ENM's 'Encounters' exhibition, the design partly overshadows the curators' voice. The ambiguous visual language of the ENM exhibition may be a challenge for visitors. At Vabamu, the curators' voice as an interpreter remains weaker beside the performative effects. The common trend that is expressed most 
explicitly at Vabamu, but which also concerns the ENM, is that in places the curators tend to rely too strongly on the experiential knowledge of contemporaries of the Soviet period. The inclusion of a wide circle of curators and different institutions is justified, but managing the team to achieve a holistic result is a challenge.

It is the responsibility of the researcher in historical science, and of the researcher-curator in the traditional museum, to create a big picture out of subjective viewpoints. Taking into account the ideological and authoritarian exhibitions during the Soviet occupation, the striving for a democratic museum experience sought by the Estonian and Latvian reforming museums is quite understandable. All three museums studied have succeeded in increasing their social relevance, by highlighting previously understudied aspects of the Soviet era, particularly those related to the individual's viewpoint and everyday life. Our findings support the ideas expressed by Eglè Rindzevičiūtè in her comparative studies of Baltic museums that their exhibitions cannot be interpreted as a reflection of some static official and/or nationalist discourse imposed by the authorities. In the case of the three new exhibitions, their content and form are the results of institutionally independent processes. They provide evidence not only of different approaches but also of the different abilities of the managers to integrate academic, design and communication competencies into a comprehensive yet multi-vocal whole. The current trend in shared authority is a sort of experiment, in which some of the interpretation is left for the visitor. Instead of the democratic equality that is striven for, the result may be that a visitor without sound knowledge is left without a supporting generalisation. On the other hand, the alternative views of different museums together on the Soviet period offer the visitor rewarding multi-vocality.

Author Details

Anu Kannike PhD

Address: Estonian National Museum, Estonia

ORCID: oooo-ooo2-3087-9314

Email: Anu.Kannike@erm.ee

Jana Reidla PhD

Address: University of Tartu, Estonia

Email: jana.reidla@ut.ee 


\section{Acknowledgments}

We would like to thank the curators who allowed us to interview them. This work was supported by the Estonian Research Council, grant 1097 .

\section{Table 1}

\begin{tabular}{|c|c|c|c|}
\hline $\begin{array}{l}\text { Museum and } \\
\text { exhibition }\end{array}$ & $\begin{array}{l}\text { Opening } \\
\text { date }\end{array}$ & Thematic structure (Soviet-era topics in bold) & $\begin{array}{l}\text { Time- } \\
\text { frame }\end{array}$ \\
\hline $\begin{array}{l}\text { Estonian } \\
\text { National } \\
\text { Museum } \\
\text { 'Encounters' }\end{array}$ & $\begin{array}{l}\text { October } \\
2016\end{array}$ & $\begin{array}{l}\text { - Journeys in Time (Time of Freedoms, Life Be } \\
\text { hind the Iron Curtain, Modern Times, } \\
\text { The Era of Books, The Arrival of Christianity, } \\
\text { The Metal Age, The Stone Age) } \\
\text { - People and the Environment } \\
\text { - My Own Abode } \\
\text { - The Runo Song } \\
\text { - The People and the State } \\
\text { - Food We Cook } \\
\text { - The Imprint of Time on Estonian Wraps } \\
\text { - Participation Hall } \\
\text { - The Language Brew } \\
\text { - Parallel Worlds. Parallel Lives } \\
\text { - Rural Life and Rural Beauty } \\
\text { - Cities within a City }\end{array}$ & $\begin{array}{l}8700 \\
\mathrm{BC}-2 \mathrm{O} 15\end{array}$ \\
\hline $\begin{array}{l}\text { National His- } \\
\text { tory Museum } \\
\text { of Latvia } \\
\text { 'Latvia's } \\
\text { Century' }\end{array}$ & May 2018 & $\begin{array}{l}\text { - Introduction: Land. People. Nation } \\
\text { - Road to the Latvian State: World War I 1914-1918 } \\
\text { - Defending Latvia's Statehood: The War of Inde } \\
\text { pendence 1918-1920 } \\
\text { - Latvia in the Making: Democratic Republic } \\
\text { 1920-1934 } \\
\text { - Latvian Latvia: Karlis Ulmanis' Authoritarian } \\
\text { Regime 1934-1940 } \\
\text { - The Suppressed State: Occupation and World } \\
\text { War II 1940-1945 } \\
\text { - Attempted Destruction of Latvia: Stalin's } \\
\text { Rule 1945-1953 } \\
\text { - Latvia as a Personal Space: Under the Soviet } \\
\text { System 1953-1985 } \\
\text { - Desire for Statehood: Restoration of Latvian } \\
\text { Independence } 1986-1991 \\
\text { - Challenges of Democracy: Creating Modern } \\
\text { Latvia 1991-20o4 } \\
\text { - Project Stories of Latvian Families }\end{array}$ & $\begin{array}{l}1914- \\
2004\end{array}$ \\
\hline $\begin{array}{l}\text { Vabamu } \\
\text { Museum of } \\
\text { Occupations } \\
\text { and Freedom } \\
\text { 'Freedom } \\
\text { Without } \\
\text { Borders' }\end{array}$ & July 2018 & $\begin{array}{l}\text { - Inhumanity } \\
\text { - Exile } \\
\text { - Soviet Estonia } \\
\text { - Recovery } \\
\text { - Freedom }\end{array}$ & $\begin{array}{l}1941- \\
2004\end{array}$ \\
\hline
\end{tabular}




\section{Bibliography}

ALATALU, Riin. 'Muinsuskaitse siirdeühiskonnas 1986-2002. Heritage protection in transitional society 1986-2002.' in: Dissertationes Academiae Artium Estoniae 10 ( $\mathrm{PhD}$ dissertation, Tallinn, 2012).

ANSTETT, Elisabeth. 'Memory of political repression in post-Soviet Russia: the example of the Gulag,' in: Online Encyclopedia of Mass Violence, (2011). https://www.sciencespo.fr/mass-violence-war-massacre-resistance/ en/document/memory-political-repression-post-soviet-russia-example-gulag.html (accessed 20210420 ).

ARNOLD, Ken. 'Thinking things through: reviving museum research', in: Science Museum and Research, Spring, (2016). DOI: http://dx.doi. org/10.15180/160505.

BADICA, Simina. 'The Black Hole Paradigm: Exhibiting Communism in Post-Communist Romania, in: History of Communism in Europe, No 1 (2010), pp. 83-101.

BOGUMIL, Zuzanna. 'Stone, Cross and Mask: Searching for Language of Commemoration of the Gulag in the Russian Federation,' in: Polish Sociological Review, Vol. 177, No 1 (2012), pp. 71-90.

Borders of Socialism. Private Spheres in Soviet Russia, ed. L. Siegelbaum (New York, 2006).

BREN, Paulina, NEUBURGER, Mary. Communism Unwrapped: Consumption in Cold War Eastern Europe (Oxford: Oxford University Press, 2012).

BURCH, Stuart, ZANDER, Ulf. 'Preoccupied by the Past: The Case of Estonia's Museum of Occupations,' in: Scandia, Vol. 74, No 2 (2010), pp. $53^{-73}$.

Contemporary Curating and Museum Education, eds. C. Morsch, A. Sachs, T. Sieber (Bielefeld, 2017).

Crimes against Humanity. Latvian Site. http://lpra.vip.lv/angliski.htm (accessed 20210420 ).

Estonia 1940-1945: reports of the Estonian International Commission for the Investigation of Crimes Against Humanity, eds. T. Hiio, M. Maripuu, I. Paavle (Tallinn, 2006).

EWIN, Timothy A.M., EWIN, Joanne, V. 'In defence of the curator: Maximising museum impact', in: Museum Management and Curatorship, Vol. 31, No 4 (2016), pp. 322-330.

GREENE, Candace S. 'Museum Anthropology', in: Emerging Trends in the Social and Behavioral Sciences: An Interdisciplinary, Searchable, and Linkable Resource, eds. R. Scott, S. Kosslyn (New York, 2015), pp. 1-15. 
HEIN, E. George. 'Museum Education', in: A companion to museum studies, ed. S. McDonald (Oxford, 2007), pp. 340-352.

HOOPER-GREENHILL, Eilean. 'Changing Values in the Art Museum: Rethinking communication and learning', in: International Journal of Heritage Studies, Vol. 6, No 1 (200o), pp. 9-31.

JIRGENSONE, Anita. 'Baltic Museology School: an example of collaboration in sharing and popularization of International Knowledge', in: Problems and Development Perspectives of Post-Soviet Countries Museums. International Scientific Conference Proceedings, Tbilisi, Georgia, November 7-10, 2015 (Tbilisi), pp. 230-235.

JÕESALU, Kirsti, NUGIN, Raili. 'Reproducing Identity Through Remembering: Cultural Texts on the Late Soviet Time', in: Folklore. Electronic Journal of Folklore, Vol. $5^{1}$ (2012), pp. 15-48.

JÕESALU, Kirsti, KÕRESAAR, Ene. 'Continuity or Discontinuity: On the Dynamics of Remembering 'Mature Socialism' in: Estonian Post-Soviet Remembrance Culture', in: Journal of Baltic Studies, Vol. 44, No 2 (2013), pp. 177-203.

KANNIKE, Anu, REIDLA, Jana. 'Vabadusel ei ole piire? Museoloogiline pilk Vabamu uuele püsinäitusele', in: Tuna. Ajalookultuuri ajakiri, No 1 (2019), pp. 139-146.

Key Concepts of Museology, eds. A. Desvallees, F. Mairesse (Paris, 2010).

KHAZANOV, Anatoly M. 'Selecting the Past: The Politics of Memory in Moscow's History Museums', in: City \& Society, Vol. 12, No 2 (2008), pp. $35^{-62 .}$

Kohtumised: Eesti kultuuriloo püsinäitus Eesti Rahva Muuseumis. Exhibition catalogue (Tartu, 2018).

KURG, Andres. 'Boundary Disruptions: Late-Soviet Transformations in Art, Space and Subjectivity in Tallinn 1968-1979', in: Dissertationes Academiae Artium Estoniae 15 (PhD dissertation, Tallinn, 2014).

KÕIV, Henri. 'Privilegeeritud ajaloo lõpp: muuseum depolitiseerimas okupatsiooni', in: Müürileht, 21 February 2017. https://www.muurileht. ee/privilegeeritud-ajaloo-lopp-muuseum-depolitiseerimas-okupatsiooni/ (accessed 202102 o8).

KÕRESAAR, Ene. 'Life story as cultural memory: Making and mediating Baltic socialism since 1989', in: Journal of Baltic Studies, Vol. 47, No 4 (2016), pp. 1-19.

KÕRESAAR, Ene, JÕESALU, Kirsti. 'Post-Soviet memories and 'memory shifts' in Estonia', in: Oral History, Vol. 47 (2016), p. 47.

KÕRESAAR, Ene, JÕESALU, Kirsti. 'Okupatsioonide muuseumist Vabamuks: Nimetamispoliitika analüüs', in: Eesti Rahva Muuseumi aastaraamat, 6o (2017), pp. 136-161. 
Latvia's Century: Museums for Latvia's 1ooth anniversary. Exhibition catalogue (Riga, 2018).

LUBAR, Steven. 'Curator as Auteur', in: The Public Historian, Vol. 36, No 1 (2014), pp. 71-76.

MCCALL, Vikki, GRAY, Clive. "Museums and the "new museology": Theory, practice and organisational change', in: Museum Management and Curatorship, Vol. 29, No 1 (2014), pp. 19-35.

MACDONALD, Sharon. 'Expanding Museum Studies: An Introduction', in: A Companion to Museum Studies, ed. Macdonald, S. (Oxford, 2006), pp. 1-12.

MACDONALD, Sharon. 'Collecting Practices', in: A Companion to Museum Studies, ed. Macdonald, S. (Oxford, 2006), pp. 81-97.

MISZTAL, Barbara. Theories of Social Remembering (London, 2003).

MESZAROS, Cheryl. 'Now THAT is evidence. Trackling down the evil "whatever" interpretation', in: Visitor Studies Today, Vol. 9, No 3 (2006), pp. $10-15$.

NIELSEN, Jane K. 'The relevant museum: defining relevance in museological practices', in: Museum Management and Curatorship, Vol. 30, No 5 (2015), pp. 364-378.

ONKEN, Eva-Clarita. 'Memory and Democratic Pluralism in the Baltic States - Rethinking the Relationship', in: Journal of Baltic Studies, Vol. 41, No 3 (2010), pp. 277-294.

PÄÄBO, Heiko; PETTAI, Eva-Clarita. 'A Museum of Memories: The New "Vabamu" in Tallinn', in: Cultures of History Forum, 27 March 2019.

RAHI-TAMM, Aigi. 'Our Untold Stories: remembering the Soviet time from a historian's viewpoint', in: Cultural Patterns and Life Stories, ed. K. Jõesalu, A. Kannike (2016), pp. 77-103.

RATTUS, Kristel. 'Paljuhäälne Eesti: Kultuuriloo püsinäituse 'Eestimaa kahekõned' koostamisest Eesti Rahva Muuseumis', in: Õpetatud Eesti Seltsi aastaraamat (Tartu, 2014), pp. 101-120.

RATTUS, Kristel. 'Dialoogilisus Eesti Rahva Muuseumi püsinäitusel "Kohtumised"', in: Eesti Rahva Muuseumi aastaraamat, 59 (Tartu, 2016), pp. $142-161$.

RATTUS, Kristel, ANEPAIO, Terje. 'Managing the Other: Stories of the Estonian Russian-speakers in the Estonian National Museum's core exhibition', in: Difficult Issues. ICOM International Conference 21-23 September 2017 Helsingborg. Proceedings, ed. A. Ziemer (Heidelberg, 2019), pp. 93-104.

REIDLA, Jana. 'Who is Leading the Project? A Comparative Study of Exhibition Production Practices at National Museums in Finland and the Baltic States', in: Museum and Society, Vol. 18, No 4 (2020), pp. 368-385. 
REIDLA, Jana. 'Curator as an expert and mediator in the paradigm of the new museum: a comparative case study of the Baltic and Finnish national museums', in: Dissertationes Ethnologiae Universitatis Tartuensis (PhD dissertation, Tartu, 2021).

RINDZEVIČIŪTĖ, Eglè. 'The Overflow of Secrets: The Disclosure of Soviet Repression in Museums as an Excess', in: Current Anthropology Vol. 56, No S12 (2015), pp. $276-285$

RINDZEVIČIŪTĖ, Eglè. 'Hegemony or Legitimacy. Assembling Soviet Deportations in Lithuanian Museums,' in: Maps of Memory. Trauma, Identity and Exile in Deportation Memoirs from the Baltic States, ed. V. Davoliūtè, T. Balkelis (Vilnius, 2012), pp. 153-177.

RINDZEVIČIŪTĖ, Eglè. 'Boundary Objects of Communism. Assembling the Soviet Past in Lithuanian Museums,' in: Ethnologie francaise, Vol. 48, No 2 (2018), pp. 275-286.

RUNNEL, Pille, PRUUlMANN-VENGERFELDT, Pille. 'The challenge of democratizing the museum', in Democratising the Museum: Reflections on Participatory Technologies, eds. P. Runnel, P. PruulmannVengerfeldt (Frankfurt-am-Main, 2014), pp. 9-16.

RUNNEL, Pille, TATSI, Taav, PRUULMANN-VENGERFELDT, Pille. 'Who Authors the Nation? The Debate Surrounding the Building of the New Estonian National Museum', in: Democratising the Museum: Reflections on Participatory Technologies, ed. P. Runnel, P. PruulmannVengerfeldt (Frankfurt-am-Main, 2014), pp. 19-34.

SANDELL, Richard. 'Museums as Agents of Social Inclusion', in: Museum Management and Curatorship, Vol. 17, No 4 (1998), pp. 401-418.

SARKISOVA, Oksana, APRO, Peter. Past for the Eyes. East European Representations of Communism in Cinema and Museums after 1989 (Budapest, 2008).

SCHULZE, Mario. 'Things are Changing: Museums and the Material Turn', in: Museological Review, No 18 (2014), pp. 43-52.

Socialist Spaces: Sites of Everyday Life in the Eastern Block, eds. D. Crowley, S. Reid (Oxford: Berg Publishers, 2002).

THOMAS, Nicholas. 'The museum as method (revisited)', in: Curatopia. Museums and the Future of Curatorship, eds. P. Schorch, C. McCarthy, (Manchester, 2020), pp. 19-28.

VELMET, Aro. 'Occupied Identities: National Narratives in Baltic Museums of Occupations', in: Journal of Baltic Studies, Vol. 42, No 2 (2011), pp. 189-211.

VELMET, Aro. 'Breaking the Silences: Contradiction and Consistency in Representing Victimhood in Baltic Museums of Occupations,' in: Nar- 
ratives of Exile and Identity in Soviet Deportation Memoirs from the Baltic States, ed. T. Balkelis, V. Davoliute (Budapest-New York, 2018), pp. 187-211.

VERGO, Peter. 'The Reticent Object', in: The New Museology, ed. P. Vergo (London, 1989), pp. 41-59.

VIAU-COURVILLE, Mathieu. 'Museums Without (Scholar-)Curators: Exhibition-Making in Times of Managerial Curatorship', in: Museum International, Vol. 68 (2017), pp. 11-32.

YURCHAK, Alexei. Everything Was Forever Until It Was No More: The Last Soviet Generation (Princeton, 2005).

\section{SOCIALINIO AKTUALUMO LINK: ESTIJOS IR LATVIJOS MUZIEJŲ KURATORIŲ NAUJOS SOVIETINIO PERIODO INTERPRETACIJOS}

Santrauka

\section{ANU KANNIKE, JANA REIDLA}

Tyrinejjant socializmą, biografinė prieiga ir dėmesys kasdieniam gyvenimui sulaukè pripažinimo tiek istorijos, tiek ir socialiniuose moksluose. Šios metodologinès kryptys siejasi su pritraukimo ir dialogo principais, kurie akcentuojami šiuolaikinėse muziejų studijose. Pastaruoju metu Estijos ir Latvijos centriniai muziejai parengė naujas ekspozicijas, kurios grindžiamos šiomis teminėmis muzeologinėmis prieigomis bei kartu atspindi istorinių tyrimų rezultatus. Šiame straipsnyje lyginamos pagrindinių ekspozicijų temos bei kuratorių pasirinkimai Latvijos nacionaliniame istorijos muziejuje, Estijos nacionaliniame muziejuje ir Vabamu muziejuje. Nors juose ir naudojamos panašios prieigos, bet tuo pat metu pateikiamos šiek tiek skirtingos sovietinio laikotarpio interpretacijos. Straipsnio autorès diskutuoja daugiabalsiškumo tema, kuria naudojamasi istorijos moksle, atminties studijose ir muzeologijoje, bei tiria iššūkius, susijusius su socialinès relevancijos siekiu šiose atminties institucijose. Analizėje žvelgiama i ginčytinas sovietinio laikotarpio temas atskleidžiančio kuratoriaus kaip tyrinètojo vietą.

Palyginti su kitomis posovietinėmis šalimis, Baltijos valstybės nedemonstruoja didelès nostalgijos sovietiniam laikotarpiui. Kita vertus, nuo XX a. paskutiniojo dešimtmečio šios temos atminimas ir reprezentacija sukèlè aktyvias diskusijas viešojoje erdvèje. Populiariojoje kultūroje ir medijose linkstama prie suprastinto sovietinio laikotarpio pateikimo, kai i pirmą planą daugiausiai iškeliami kasdieniai mitai ir simboliai. Bet, nepaisant šio konteksto, naujieji muziejai prisiẻmẻ vadovaujantị vaidmenį ir atsakomybę pritatydami sovietinius laikus.

Visose trijose parodose taikomas biografinis metodas. Pateikiama individualios istorijos patirtis rodo muziejų demokratizaciją - i pirmą planą iškeliamos ne istorinių asmenybių biografijos, bet paprastų žmonių kasdieniuose gyvenimuose įvykę pokyčiai. Latvių paroda išryškina daugiatautiškumą, o Estijos nacionalinis muziejus akcentuoja imigracijos ir paralelinių bendruomenių temas, Vabamu ekspozicija ryšius tarp individo ir režimo. 
Siekiant harmonizuoti parodų kuratorių balsus, efektyvų grupinį darbą, išgryninti pagrindinių kuratorių požiūrių aspektus, būtinas tarpmuziejinis bendradarbiavimas. Latvijos nacionalinio istorijos muziejaus ir Estijos nacionalinio muziejaus patirtys atskleidžia, kad plataus kuratorių būrio ir ịvairių institucijų įtraukimas pasiteisina. Vabamu muziejus labiau orientuotas ị jaunimą, tačiau parodos rezultatuose atsispindi, kad yra įtrauktos ir svarbios tikslinès - vyresnès ir vidurinės kartų represuotuju ir kovotojų už laisvę bei žymių akademinių tyrinėtojų - grupès.

Turint galvoje ideologiškai paveiktas ir autoritarines sovietinès okupacijos metų ekspozicijas, noras sukurti daugiabalses ir demokratines muziejų patirtis, kurių siekia Estijos ir Latvijos reformuojami muziejai, yra visiškai suprantamas. Tačiau šiuolaikinė tendencija dalintis autoritetu yra savotiškas eksperimentas, kai dalis interpretacijų paliekama parodų lankytojams. Tai sukelia tam tikrą riziką, nes lankytojas, turintis menkų žinių, gali likti be kontekstinès informacijos ar pagrịstų apibendrinimų. Kita vertus, trijų Baltijos muziejų alternatyvus požiūris ị sovietinị laikotarpi siūlo lankytojui papildomas patirtis. Daugiabalsiškumo akcentavimas prisideda prie margesnio sovietinio laikotarpio paveikslo nei buvusios ekspozicijos ir leidžia daryti naujus analitinius palyginimus. 